\title{
Zakres przedmiotowy tzw. uchwały krajobrazowej. Uwagi na tle wyroku Wojewódzkiego Sądu Administracyjnego w Gdańsku z 18 września 2018 r., sygn. II SA/Gd 328/18
}

\section{Wprowadzenie}

Możliwość uchwalania przez rady gmin tzw. uchwał krajobrazowych na podstawie art. 37a Ustawy z dnia 27 marca 2003 r. o planowaniu i zagospodarowaniu przestrzennym ${ }^{1}$ wprowadzona została w $2015 \mathrm{r}$. w wyniku wejścia w życie Ustawy z dnia 24 kwietnia 2015 r. o zmianie niektórych ustaw w związku ze wzmocnieniem narzędzi ochrony krajobrazu ${ }^{2}$. Zgodnie z dodanym wówczas art. 37a ust. 1 u.p.z.p. uchwała ta określa zasady i warunki sytuowania obiektów małej architektury, tablic reklamowych i urządzeń reklamowych oraz ogrodzeń, ich gabaryty, standardy jakościowe oraz rodzaje materiałów budowlanych, z jakich mogą być wykonane. W art. 37a ust. 2 u.p.z.p. uwzględniono zaś specyfikę szyldów, wskazując, że uchwała krajobrazowa może ustalać zasady i warunki ich sytuowania, gabaryty oraz liczbę szyldów, które mogą być umieszczone na danej nieruchomości przez podmiot prowadzący na niej działalność. Wskazano również na możliwość ustalenia całkowitego zakazu sytuowania ogrodzeń oraz tablic reklamowych i urządzeń reklamowych, z wyłączeniem szyldów (art. 37a ust. 3 u.p.z.p.). Warto wspomnieć, że przyjęcie uchwały krajobrazowej powinno być poprzedzone licznymi konsultacjami

* Agata Lizak, mgr, Uniwersytet Rzeszowski, e-mail: agata_lizak@interia.pl,https:// orcid.org/0000-0002-0450-1828.

${ }^{1}$ Tekst jedn. Dz.U. 2018, poz. 1945 ze zm., dalej „u.p.z.p.”.

${ }^{2}$ Dz.U. 2015, poz. 774 ze zm., dalej „u.k.”. 
przeprowadzanymi na mocy art. 37b u.p.z.p. zarówno z organami administracji publicznej, jak i innymi podmiotami, np. mieszkańcami. Co więcej, nieprzestrzeganie przepisów tego typu uchwały obwarowane zostało sankcją w postaci kary pieniężnej, o której mowa w art. 37d u.p.z.p.

Mimo kilkuletniego okresu obowiązywania wyżej wymienionych przepisów na przyjęcie uchwały krajobrazowej zdecydowało się mniej niż $1 \%$ wszystkich gmin ${ }^{3}$, co dowodzi iluzoryczności instrumentów ochronnych w skali krajowej. Podejmowaniu decyzji w sprawie uchwał krajobrazowych nie sprzyja niejasność postanowień ustawy o planowaniu i zagospodarowaniu przestrzennym, a także wątpliwości co do konstytucyjności samych uchwał w zakresie, w jakim nie przewidują one ochrony prawnej (mechanizmów kompensacyjnych) dla podmiotów, które w efekcie ich wejścia w życie traca prawo do umieszczania reklam na dotychczasowych zasadach ${ }^{4}$. Problemem może być również potencjalne ryzyko naruszenia zasad konkurencji ${ }^{5}$ czy niepewność co do samego prawa, pojawiająca się wobec na razie bardzo wstępnych planów uchwalenia nowego prawa planowania i zagospodarowania przestrzennego ${ }^{6}$.

O trudnościach w odpowiednim ukształtowaniu treści uchwały krajobrazowej świadczą długotrwałe spory sądowe, jakie niejednokrotnie są

${ }^{3}$ Zob. https://jetline.pl/aktualnosci/08-gmin-w-polsce-ma-uchwale-krajobrazowa-raport-na-dzien-28-lutego-2019-r, stan na 28 II 2019 r. (dostęp: 9 II 2020).

${ }^{4}$ Zob. postanowienie Naczelnego Sądu Administracyjnego (NSA) z 6 VI 2019 r., sygn. II OSK 166/18, LEX nr 2715853, dotyczące skierowania w tej sprawie pytania do Trybunału Konstytucyjnego. Jak podkreślił NSA w postanowieniu, „wątpliwości konstytucyjne budzi w niniejszej sprawie nie sama dopuszczalność ingerencji polegającej na odebraniu wynikającego z uzyskanej zgody budowlanej prawa do korzystania z nieruchomości poprzez konieczność likwidacji tablic i urządzeń reklamowych, która jest uzasadniona dbaniem o dobro wspólne, tj. wspólną przestrzeń urbanistyczna, i wynika przede wszystkim z art. 1 i art. 5 Konstytucji RP oraz unormowań Europejskiej Konwencji Krajobrazowej sporządzonej we Florencji dnia 20 października 2000 r. (Dz. U. z 2006 r. Nr 14, poz. 98). Przedmiotem wątpliwości jest brak odpowiedniego mechanizmu kompensacyjnego z tytułu pozbawienia prawa do korzystania z mienia oraz wyrządzonej tym samym szkody legalnej".

${ }^{5}$ Zob. https://www.prawo.pl/samorzad/reklamy-w-warszawie-zbada-uokik-pod-katem-stworzenia-monopolu,497734.html (dostęp: 9 II 2020).

${ }^{6}$ Dnia 27 V 2019 r. do tzw. prekonsultacji przekazano projekt ustawy - Prawo planowania i zagospodarowania przestrzennego. Zgodnie z projektem uchwały krajobrazowe miałyby zostać zastapione przez gminne standardy urbanistyczne o szerszym zakresie przedmiotowym (choć w zakresie sytuowania obiektów małej architektury, tablic reklamowych i urządzeń reklamowych oraz ogrodzeń powielono treść obecnego art. 37a ust. 1 u.p.z.p.). W związku z projektem wciąż nie rozpoczęto oficjalnego procesu legislacyjnego. 
konsekwencją zaskarżania tego typu uchwał przez uprawnione podmioty $^{7}$. Kwestia prawidłowości ustalenia zakresu przedmiotowego uchwały krajobrazowej była rozważana w wyroku Wojewódzkiego Sądu Administracyjnego (WSA) w Gdańsku z dnia 18 września 2018 r., sygn. II SA/Gd 328/18 , którego tezy stanowią podstawę dalszych analiz. Orzeczenie to należy uznać za o tyle ciekawe, że dotyczy ono trzech konkretnych, a jednocześnie, jak się wydaje, powszechnie występujących problemów, jakie mogą pojawić się w gminach w związku z uchwałami krajobrazowymi. Po pierwsze, w wyroku przeanalizowano, czy uchwała krajobrazowa może dotyczyć materiałów wyborczych lub referendalnych, po drugie - rozważono, w jaki sposób uchwała ta może ingerować w umieszczanie reklam i urządzeń reklamowych przy skrzyżowaniach, przejazdach kolejowych, mostach, wiaduktach, estakadach oraz tunelach, po trzecie zaś - przesądzono, czy istnieje możliwość nakładania na adresatów uchwały obowiązku utrzymania reklam w należytym stanie. Co interesujące, w orzeczeniu odniesiono się także do kwestii relacji postanowień u.p.z.p. i wydawanych na ich podstawie uchwał krajobrazowych do innych aktów prawnych. Należy dodać, że wyrok ma charakter prawomocny.

\section{Podstawowe informacje na temat przebiegu sprawy}

Przed przejściem do analizy problemów poruszonych w wyroku warto nakreślić istotę stanu faktycznego. W dniu 22 lutego 2018 r. Rada Miasta G. podjęła uchwałę w sprawie ustalenia zasad i warunków sytuowania obiektów małej architektury, tablic reklamowych oraz ogrodzeń, ich gabarytów, standardów jakościowych oraz rodzajów materiałów budowlanych, z jakich mogą być wykonane, na terenie miasta G. Uchwała ta stała się przedmiotem rozstrzygnięcia nadzorczego wojewody, który stwierdził nieważność części jej postanowień. W pierwszej kolejności wojewoda stwierdził, że Rada Miasta G. działała z naruszeniem art. 7

${ }^{7}$ Przykładem mogą być spory wokół uchwały krajobrazowej przyjętej przez Łódź. Zaskarżona przez Wojewodę Łódzkiego w 2016 r., była przedmiotem wyroku WSA w Łodzi z 11 VIII 2017 r., sygn. II SA/Łd 523/17, LEX nr 2353893, w którym stwierdzono jej nieważność. Wyrok ten ponad dwa lata później uchylił NSA w wyroku z 15 X 2019 r., sygn. II OSK 2880/17, LEX nr 2759132, przekazując sprawę do ponownego rozpoznania (które na dzień sporządzania niniejszego tekstu, tj. 9 II 2020 r., jeszcze nie nastąpiło).

${ }^{8}$ Wyrok WSA w Gdańsku z 18 XII 2018 r., sygn. II SA/Gd 328/18, LEX nr 2556366. 
Konstytucji Rzeczypospolitej Polskiej ${ }^{9}$ w zakresie, w jakim uchwałą krajobrazową objęła reklamy wyborcze. Zdaniem wojewody kwestia ich sytuowania wyczerpująco uregulowana została w Ustawie z dnia 5 stycznia 2011 r. - Kodeks wyborczy ${ }^{10}$, a więc akcie wyższej rangi aniżeli uchwała krajobrazowa, stanowiąca jedynie akt prawa miejscowego. Kolejno, zanegowana została możliwość określenia odległości reklam i urządzeń reklamowych od elementów infrastruktury drogowej - również w tym przypadku uznano, za regułą lex superior derogat legi inferiori, że postanowienia uchwały krajobrazowej bezprawnie ingerują w kwestię uregulowaną w Ustawie z dnia 21 marca 1985 r. o drogach publicznych ${ }^{11}$. Ponadto uznano, że poza delegację ustawową wykracza nałożenie na adresatów uchwały obowiązku utrzymywania urządzeń reklamowych, obiektów małej architektury i ogrodzeń - zdaniem wojewody obowiązek ten nie jest związany ani z sytuowaniem wyżej wskazanych elementów, ani z wyznaczeniem ich standardów jakościowych, a co więcej - został już wyrażony w Ustawie z dnia 7 lipca 1994 r. - Prawo budowlane ${ }^{12}$.

Na rozstrzygnięcie nadzorcze skargę wniosła Rada Miasta G., zarzucając naruszenie art. 91 ust. 1 i 3 Ustawy z dnia 8 marca 1990 r. o samorządzie gminnym ${ }^{13}$, wskazując na wadliwość uzasadnienia rozstrzygnięcia, a także art. 37a u.p.z.p. w związku z odpowiednimi przepisami kodeksu wyborczego, ustawy o drogach publicznych i prawa budowlanego oraz art. 7 Konstytucji RP, poprzez błędne uznanie, że przyjmując uchwałę krajobrazową w zanegowanym brzmieniu, Rada Miasta G. przekroczyła delegację ustawową.

$Z$ argumentacją strony zgodził się Sąd, który, uznawszy, że zakwestionowane przepisy uchwały krajobrazowej nie stoją w sprzeczności z prawem, uchylił zaskarżone rozstrzygnięcie nadzorcze. Przedmiotowy wyrok, jak również tok rozumowania przedstawiony w jego uzasadnieniu co do zasady zasługują na aprobatę, aczkolwiek warto bardziej szczegółowo przyjrzeć się podniesionym przez sąd argumentom, odnosząc je do przepisów ustawy o planowaniu i zagospodarowaniu przestrzennym, a także konfrontując z dotychczasowym dorobkiem orzeczniczym w zbliżonych stanach faktycznych.

${ }^{9}$ Konstytucja Rzeczypospolitej Polskiej z dnia 2 IV 1997 r. (Dz.U. Nr 78, poz. 48 ze zm.), dalej „Konstytucja RP”.

${ }^{10}$ Tekst jedn. Dz.U. 2019, poz. 684 ze zm., dalej „k.w.”.

${ }^{11}$ Tekst jedn. Dz.U. 2018, poz. 2068 ze zm., dalej „u.d.p.”.

12 Tekst jedn. Dz.U. 2019, poz. 1186 ze zm., dalej "p.b.".

13 Tekst jedn. Dz.U. 2019, poz. 506 ze zm., dalej „u.s.g.”. 


\section{Uchwała krajobrazowa a kwestia reklam wyborczych}

W będącej przedmiotem wyroku uchwale krajobrazowej Rada Miasta G. sformułowała własną definicję reklamy wyborczej, uznając, że jest nią "materiał wyborczy, referendalny lub reklama kandydatów do Rad Jednostek Pomocniczych sytuowana na potrzeby kampanii wyborczych (parlamentarnych, prezydenckich, do jednostek samorządu terytorialnego lub do Rad Jednostek Pomocniczych)". W ocenie Sądu tak ustalona definicja reklamy wyborczej mieści się w zakresie pojęcia „reklama”, zdefiniowanego w art. 2 pkt 16a u.p.z.p. jako upowszechnianie w jakiejkolwiek wizualnej formie informacji promującej osoby, przedsiębiorstwa, towary, usługi, przedsięwzięcia lub ruchy społeczne, a przez to nie stanowi wykroczenia poza delegację ustawową. Odnosząc się do tego argumentu, w istocie wskazać należy, że w typowym przypadku plakaty wyborcze mają na celu promocję konkretnych osób; brak jest zatem powodów, by traktować je odmiennie od reklam w rozumieniu u.p.z.p.

Więcej wątpliwości może nasunąć się w kontekście pominiętego przez Sąd faktu, że sformułowana przez Radę Miasta G. definicja obejmuje materiały wyborcze i referendalne, mogące przecież dotyczyć kwestii szerszych aniżeli agitacja za konkretnym kandydatem ${ }^{14}$. Do wyobrażenia jest bowiem sytuacja, gdy dany komitet wyborczy publikuje materiały wyłącznie informujące o terminie głosowania lub o liście kandydatów, bez elementów ich promocji. Specyficzne są również kampanie referendalne, których przedmiot nie tylko zazwyczaj nie wiąże się z promocją osoby, ale w których też niejednokrotnie, przynajmniej prima facie, trudno mówić o promocji jakiegokolwiek przedsięwzięcia czy ruchu społecznego (np. w przypadku referendum w sprawie odwołania wójta). Niemniej jednak w literaturze można znaleźć postulaty możliwie szerokiej wykładni pojęcia przedsięwzięcie, które miałoby być rozumiane jako każde zamierzenie, zarówno o charakterze komercyjnym, jak

${ }^{14}$ Można również znaleźć stanowiska, zgodnie z którymi materiały wyborcze, ze względu na definicję z art. 109 k.w., stanowiąca, że ich istotą jest przekaz informacji, są pojęciem całkowicie rozłącznym od agitacji, polegającej według art. 105 k.w. na publicznym nakłanianiu i zachęcaniu do głosowania w określony sposób. Niemniej podejście takie uznaje się za zbyt restrykcyjne, także w orzecznictwie, zgodnie z którym materiałami wyborczymi są plakaty, ulotki, billboardy, napisy, komunikaty, apele (wyrok Sądu Apelacyjnego w Krakowie z 6 XII 2012 r., sygn. I ACz 1253/12, LEX nr 1216305). Zob. też: B. Banaszak, Kodeks wyborczy. Komentarz, Warszawa 2020. 
i niekomercyjnym ${ }^{15}$. Ponadto, na mocy przepisów odrębnych, zarówno materiały wyborcze, jak i referendalne powinny zawierać oznaczenie, od kogo pochodzą. W tym kontekście można uznać, że umieszczenie na materiałach logo konkretnego komitetu/podmiotu jest automatycznie promocją jego samego ${ }^{16}$.

Jak zatem widać, istnieją także nieprzytoczone wprost przez Sąd argumenty, że definicja reklamy wyborczej sformułowana w uchwale krajobrazowej miasta G. mieści się w zakresie pojęcia "reklama” z art. 2 ust. 16a u.p.z.p. Jak słusznie stwierdził WSA w Gdańsku, definicja materiałów wyborczych, rozumianych jako każdy pochodzacy od komitetu wyborczego upubliczniony i utrwalony przekaz informacji mający związek z zarządzonymi wyborami, nie wyklucza uznania ich jednocześnie za reklamę w rozumieniu u.p.z.p. W tym aspekcie rozstrzygnięcie Sądu należy zresztą uznać za spójne z innymi orzeczeniami sądów administracyjnych, zgodnie z którymi materiał wyborczy w rozumieniu art. 109 k.w. może spełniać ustawowe definicje sformułowane $\mathrm{w}$ innych aktach prawnych ${ }^{17}$.

W swojej argumentacji Sąd słusznie uznał również, że problematyki sytuowania materiałów wyborczych nie wyczerpuje art. $110 \S 1$ k.w., zgodnie z którym na ścianach budynków, przystankach komunikacji publicznej, tablicach i słupach ogłoszeniowych, ogrodzeniach, latarniach, urządzeniach energetycznych, telekomunikacyjnych i innych można umieszczać plakaty i hasła wyborcze wyłącznie po uzyskaniu zgody właściciela lub zarządcy nieruchomości, obiektu albo urządzenia. Rozwijając tę tezę, należy zauważyć, że celem wskazanego przepisu jest sformułowanie obowiązku uzyskania zgody od konkretnych podmiotów, a nie uregulowanie zasad sytuowania materiałów pod względem ich rozmieszczenia.

Więcej wątpliwości może budzić art. 110 § 2 zd. 1 k.w., zgodnie z którym przy ustawianiu własnych urządzeń ogłoszeniowych w celu

15 A. Fogel, G. Goleń, A. Staniewska, Komentarz do art. 7 ustawy krajobrazowej, w: Ustawa krajobrazowa. Komentarz do przepisów wprowadzonych w zwiazku ze wzmocnieniem narzędzi ochrony krajobrazu, pod red. A. Fogel, Warszawa 2016.

${ }^{16} \mathrm{~W}$ odniesieniu do komitetu wyborczego należy zauważyć, że nie ma on statusu osoby fizycznej, prawnej ani jednostki organizacyjnej nieposiadającej osobowości prawnej. Niemniej trzeba pamiętać, że komitety wyborcze nie funkcjonują w próżni, a zatem ich promocja może być in concreto tożsama chociażby z promocją partii politycznej (osoby prawnej), przy której funkcjonują. Zob. też wyrok WSA w Gdańsku z 12 IX 2018 r., sygn. I SA/Gd 682/18, w którym uznano, że samo logo czy nazwa firmy stanowią reklamę, albowiem niewątpliwie reklamują konkretne przedsiębiorstwo.

17 Zob. wyrok NSA z 21 VII 2017 r., sygn. II GSK 2937/15, LEX nr 2364671, w którym uznano, że materiał wyborczy może być jednocześnie reklamą w rozumieniu u.d.p. 
prowadzenia kampanii wyborczej należy stosować obowiązujące przepisy porządkowe. Powstaje w tym zakresie pytanie: skoro ustawodawca wprost odwołał się wyłącznie do przepisów porządkowych, to czy można dodatkowo ustalać reguły dotyczące sytuowania materiałów wyborczych w aktach prawnych o innej specyfice, w tym - w uchwale krajobrazowej. Wskazać jednak należy, że po pierwsze, art. $110 \S 2$ zd. 1 k.w. dotyczy ograniczonego zakresu materiałów (tj. wyłącznie tych prezentowanych na własnych urządzeniach ogłoszeniowych), a po drugie - przepisy porządkowe regulować mają inną aniżeli estetyka przestrzeni publicznej materię ${ }^{18}$. Na marginesie, art. $110 \S 2$ zd. 1 k.w. można uznać za superfluum, gdyż przepisy porządkowe zasadniczo powinny być stosowane niezależnie od tego, czy nakazuje to ustawa mają samoistną moc powszechnie obowiązująca, a więc mogą dotyczyć sytuowania jakichkolwiek urządzeń, także "typowych" urządzeń reklamowych niezwiązanych z kampanią wyborczą. Sam obowiązek stosowania przepisów porządkowych nie powinien zatem wykluczać możliwości jednoczesnego stosowania innych regulacji.

Niemniej, analizując omawiane regulacje w szerszym kontekście, widać, że intencją ustawodawcy było umożliwienie władzom lokalnym ustalanie szczegółowych zasad sytuowania materiałów wyborczych. Powyższe dostrzegł także sąd, powołując się na art. 114 k.w., zgodnie z którym wójt niezwłocznie po rozpoczęciu kampanii wyborczej zapewni na obszarze gminy odpowiednią liczbę miejsc przeznaczonych na bezpłatne umieszczanie urzędowych obwieszczeń wyborczych i plakatów wszystkich komitetów wyborczych oraz poda wykaz tych miejsc do publicznej wiadomości w sposób zwyczajowo przyjęty oraz w Biuletynie Informacji Publicznej. Należy jednak podkreślić, że, chcąc pozostać konsekwentnym w twierdzeniu, iż regulacje kodeksu wyborczego są niezależne od postanowień uchwał krajobrazowych, przepis ten można powoływać jako argument jedynie pomocniczo. Na poparcie zasługuje jednocześnie systemowa i funkcjonalna argumentacja WSA w Gdańsku, zgodnie z którą za objęciem zakresem uchwały krajobrazowej reklam wyborczych przemawia fakt, że przepisy kodeksu wyborczego dotyczą zupełnie odrębnej materii, celem uchwał krajobrazowych jest zaś ograniczenie zagrożeń dla estetyki przestrzeni publicznej, na którą reklamy wyborcze - na równi z innymi reklamami - mogą wpływać negatywnie.

${ }^{18} \mathrm{Na}$ mocy art. 40 ust. 3 u.s.g. rada gminy może wydawać przepisy porządkowe, jeżeli jest to niezbędne dla ochrony życia lub zdrowia obywateli oraz dla zapewnienia porządku, spokoju i bezpieczeństwa publicznego. 
Zdaniem WSA w Gdańsku za możliwością uregulowania kwestii reklam wyborczych w uchwale krajobrazowej przemawia także art. 37c u.p.z.p., zgodnie z którym przepisów dotyczących reklam nie stosuje się do upowszechniania informacji wyłącznie trwale upamiętniającej osoby, instytucje lub wydarzenia bądź informacji o charakterze religijnym, związanych z działalnością Kościołów lub innych związków wyznaniowych, jeżeli tablica reklamowa czy urządzenie reklamowe sytuowane są w granicach terenów użytkowanych jako miejsca kultu i działalności religijnej oraz cmentarzy. Źródeł tego argumentu należy poszukiwać w zasadzie exceptiones non sunt extendae (mimo że Sąd wprost się na nią nie powołał). Uzupełniająco do rozważań Sądu warto zauważyć, że wskazany przepis daje podstawy do szerokiej wykładni definicji reklamy z art. 2 ust. 16a u.p.z.p., a ściślej - pojęcia "promowanie", które, jak się zdaje, może być rozumiane także jako po prostu rozpowszechnianie ${ }^{19}$. Przepis ten dotyczy materiałów o charakterze raczej informacyjnym, przy czym wyłącza je nie spod definicji samej reklamy, co ze stosowania przepisów jej dotyczących ${ }^{20}$. Potwierdza to jedynie, że również te materiały wyborcze i referendalne, w których element promocji rozumianej jako propagowanie niekoniecznie występuje, mogą zostać uznane za reklamy w rozumieniu ustawy o planowaniu i zagospodarowaniu przestrzennym.

\section{Uchwała krajobrazowa a kwestia sytuowania reklam przy elementach infrastruktury drogowej}

Kolejnym dylematem, przed jakim stanął WSA w Gdańsku w analizowanej sprawie, była kwestia relacji pomiędzy przepisami ustawy o drogach publicznych określającymi minimalne wymogi w zakresie odległości od zewnętrznej krawędzi jezdni obiektów budowlanych oraz reklam niebędących obiektami budowlanymi (w szczególności mowa

${ }^{19}$ Zob. Stownikjęzyka polskiego, gdzie wyrażenie "promować” uznaje się za tożsame z "czynić coś powszechnym, popularnym; upowszechniać, rozpowszechniać”, https:// sjp.pl/promować (dostęp: 9 II 2020).

${ }^{20}$ Według niektórych komentujących wyłączenie to stanowi nieporozumienie właśnie ze względu na brak elementów promujących na wskazanych w nim kategoriach "reklam". Zob. A. Plucińska-Filipowicz, A. Kosicki, Komentarz do art. 37 c ustawy o planowaniu i zagospodarowaniu przestrzennym, w: Ustawa o planowaniu i zagospodarowaniu przestrzennym. Komentarz aktualizowany, pod red. A. Plucińskiej-Filipowicz, M. Wierzbowskiego, Warszawa 2019. 
o postanowieniach art. 43 ust. 1 u.d.p.) a przepisami uchwały krajobrazowej. Przypomnieć należy, że w uchwale będącej przedmiotem orzeczenia ustalono zakaz sytuowania określonych reklam w odległości mniejszej niż 50 m od skrzyżowań, przejazdów kolejowych, mostów, wiaduktów, estakad i tuneli, dopuszczając ich usytuowanie w odległości do $14 \mathrm{~m}$ od krawędzi jezdni. Według wojewody skarżącego to postanowienie uchwała krajobrazowa nie powinna ingerować w ustalone już na poziomie ustawowym zasady sytuowania reklam przy drogach. Sąd uznał natomiast, że „[o]czywistym jest, iż adresaci obu wskazanych regulacji winni przestrzegać zawartych w nich norm. Przy czym zakładane skutki takich zachowań są odmienne. Dla uchwały krajobrazowej jest to ochrona krajobrazu, dla ustawy o drogach publicznych zapewnienie bezpieczeństwa ruchu drogowego". Za przesądzające uznano zatem ratio legis obu aktów prawnych.

Z powyższą argumentacją należy się zgodzić. W istocie, nawet gdyby zdarzyło się, że wymogi ustalone w uchwale krajobrazowej są mniej restrykcyjne aniżeli wymogi z u.d.p., nie znosi to samo w sobie mocy obowiązującej przepisu ustawowego ${ }^{21}$. Zwrócić należy również uwagę na to, że w praktyce odmienne przepisy uchwały i ustawy o drogach publicznych nie powinny być ze sobą w kolizji - w u.d.p. zawarto bowiem odległości minimalne, a zatem jak najbardziej dopuszczalne jest ich przekroczenie. Nie zmienia to faktu, że w uchwale krajobrazowej ingeruje się w uprawnienia jednostek, które już raz ograniczono w przepisach u.d.p. - to może rodzić pytanie o zgodność z zasadą proporcjonalności, wyrażoną w art. 31 ust. 3 Konstytucji RP22. Należy jednak wskazać, że problem, z jakim docelowo mają się uporać przepisy uchwał krajobrazowych, w dużej mierze dotyczy reklam usytuowanych nieopodal infrastruktury drogowej, gdyż to właśnie wzdłuż jej elementów najczęściej umieszczane są różnorakie materiały promocyjne. Uznanie,

${ }^{21} \mathrm{~W}$ praktyce sytuacja taka nie powinna być jednak powszechna. Należy zaznaczyć, że uchwała krajobrazowa będąca przedmiotem orzeczenia obowiązuje na terenie gminy miejskiej, będącej - jak można przypuszczać - w dominującej mierze obszarem zabudowanym według przepisów u.d.p., przez który przebiegają przede wszystkim drogi inne aniżeli autostrada czy droga ekspresowa. Dla dróg ogólnodostępnych - czy to wojewódzkich, czy krajowych, czy gminnych - minimalne odległości dla obiektów budowlanych i reklam od krawędzi jezdni wahają się w przedziale 6-8 m (zgodnie $\mathrm{z}$ art. 43 ust. 1 u.d.p.), a zatem mniejszym aniżeli określony w uchwale krajobrazowej.

${ }^{22} \mathrm{Na}$ temat potrzeby uwzględniania tego przepisu przy sporządzaniu uchwał krajobrazowych zob. T. Bąkowski, Zakres swobody $i$ władztwa planistycznego gminy w ksztattowaniu treści uchwaty krajobrazowej, "Gdańskie Studia Prawnicze” 2017, nr 2, s. 67. 
że kwestia ta została wyczerpująco uregulowana w ustawie o drogach publicznych, czyniłoby bezprzedmiotowym przyznanie radom gmin uprawnienia do określania warunków sytuowania tablic reklamowych i urządzeń reklamowych, co z kolei w świetle brzmienia art. 37a ust. 1 u.p.z.p. jest nie do pogodzenia z racjonalnością ustawodawcy.

Jednocześnie należy stwierdzić, że stanowisko WSA w Gdańsku można uznać za reprezentatywne dla linii orzeczniczej, zgodnie z którą określenie większych odległości poszczególnych obiektów od krawędzi jezdni aniżeli normowane ustawowo należy do władztwa gminy. Jak uznał NSA w wyroku z dnia 27 września 2017 r. ${ }^{23}$ w kontekście postanowień miejscowego planu zagospodarowania przestrzennego ${ }^{24}$, w świetle art. 43 ust. 1 u.d.p. sprzeczność planu z wyżej przytoczonym przepisem zachodziłaby wyłącznie wtedy, gdyby plan ten ustalał mniejszą odległość, niż została przewidziana w ustawie, lub gdyby przepis ustawy ustalał bezwzględnie jedną obowiązującą odległość w sposób sztywny. Dalej uznano, że przepisy aktów prawa miejscowego (a zatem również uchwał krajobrazowych) należy uznać za lex specialis wobec przepisów ustawowych, przy czym reguła kolizyjna, zgodnie z którą norma wyższa (ustawowa) uchylałaby niższą (prawo miejscowe) mogłaby zostać zastosowana w procesie stosowania przedmiotowych przepisów jedynie $\mathrm{w}$ razie ustalenia sprzeczności między zapisami planu ${ }^{25}$.

\section{Uchwała krajobrazowa a ustalenie obowiązku utrzymania obiektów małej architektury, tablic reklamowych i urządzeń reklamowych oraz ogrodzeń}

Istotą trzeciego problemu, o którym mowa w omawianym orzeczeniu, jest potrzeba rozstrzygnięcia, czy za pomocą uchwał krajobrazowych można ingerować wyłącznie w cechy i umiejscowienie obiektów

${ }^{23}$ Wyrok NSA z 27 IX 2017 r., sygn. II OSK 156/16, LEX nr 2379250.

${ }^{24}$ Należy w tym miejscu przypomnieć, że przed wejściem w życie przepisów dotyczących uchwały krajobrazowej, na mocy ówczesnego art. 15 ust. 3 pkt 9 u.p.z.p., zasady i warunki sytuowania obiektów małej architektury, tablic i urządzeń reklamowych oraz ogrodzeń, ich gabaryty, standardy jakościowe oraz rodzaje materiałów budowlanych, $\mathrm{z}$ jakich mogą być wykonane, regulowane mogły być w miejscowych planach zagospodarowania przestrzennego.

${ }^{25}$ Stanowisko, zgodnie z którym określanie większych odległości aniżeli wynikające z u.d.p. należy do władztwa gminy, wyrażono także w prawomocnych wyrokach WSA w Poznaniu z 2 II 2017 r., sygn. IV SA/Po 930/16, LEX nr 2230001, oraz WSA w Gorzowie Wielkopolskim z 28 I 2015 r., sygn. II SA/Go 895/14, LEX nr 1643873. 
małej architektury, tablic reklamowych i urządzeń reklamowych oraz ogrodzeń na moment ich umieszczania w przestrzeni publicznej, czy też uchwały te mogą zawierać również wymogi, których spełnienie ze swej istoty rozciągnięte jest $\mathrm{w}$ czasie. Spór w tym zakresie dotyczył konkretnie dopuszczalności ustalenia przez Radę Miasta G. warunku utrzymywania obiektów małej architektury, tablic reklamowych i urządzeń reklamowych oraz ogrodzeń. Wojewoda uznał, że stanowi to przekroczenie kompetencji wskazanych w art. 37a u.p.z.p., a ponadto jest niecelowe ze względu na to, iż problem utrzymywania urządzeń reklamowych, obiektów małej architektury i ogrodzeń jest materią innego aktu prawnego, jakim jest ustawa Prawo budowlane.

$Z$ argumentami tymi nie zgodził się jednak Sąd. W pierwszej kolejności w wyroku uznano, że pojęcie utrzymywania można zawrzeć w zakresie pojęcia "sytuowanie", które Sąd rozumie jako istnienie obiektów w określonym krajobrazie w czasie. Podejście to może jednak budzić kontrowersje, gdyż językowo wyrażenie to tożsame jest $\mathrm{z}$ umiejscawianiem, lokowaniem, umieszczaniem lub rozmieszczaniem czegoś ${ }^{26}$, co jest czynnością zasadniczo jednorazową, a ponadto wiąże się wyłącznie z miejscem, w którym dany przedmiot ma funkcjonować (a nie z cechami tego przedmiotu jako takiego).

W dalszej części orzeczenia odniesiono się z kolei do jakości materiałów, których rodzaj wskazano w art. 37a ust. 1 u.p.z.p. expressis verbis jako okoliczność możliwą do ujęcia w uchwale krajobrazowej. Sąd zauważa w tym zakresie, że na ich jakość wpływa erozja postępująca w czasie, mając wpływ na estetykę krajobrazu. Stanowisko to również można uznać za kontrowersyjne, dostrzegając w nim pewną sprzeczność z regułami życiowego doświadczenia - nie ma bowiem materiałów, które zagwarantowałyby brak zniszczeń, a tym samym niemożliwe jest określenie ich rodzaju w taki sposób, by zapewniały, że dany obiekt będzie „dobrze utrzymany" przez cały czas jego istnienia. Ponadto, co wynika z analizy art. 37a ust. 1 u.p.z.p. pod kątem językowym, spełnienie wymogu co do rodzaju zastosowanych materiałów także ma miejsce w chwili umiejscowienia danego obiektu. Skupiając się natomiast na tym, czy utrzymanie może być wyrazem spełnienia przesłanki co do standardów jakościowych (co jednak według art. 37a u.p.z.p. jest odrębną kwestią regulowaną w uchwałach aniżeli rodzaj materiałów, do którego nawiązał Sąd), należy podkreślić, że w doktrynie definiowane są

\footnotetext{
${ }^{26}$ Stownik współczesnego języka polskiego, t. 2, pod red. B. Dunaja, Warszawa 1998, s. 374.
} 
one podobnie, jak uczynił to wojewoda w rozstrzygnięciu nadzorczym, tj. jako zespół cech danego obiektu ${ }^{27}$. Wbrew podejściu organu (czego z kolei Sąd wystarczająco nie zaakcentował) wydaje się jednak, że zarówno językowo, jak i funkcjonalnie właśnie w możliwości ustalenia standardów jakościowych można by się dopatrywać podstaw do wprowadzenia w uchwale krajobrazowej przepisów określających obowiązek dbania o obiekt małej architektury, tablicę reklamowa, urządzenie reklamowe czy ogrodzenie $\mathrm{w}$ dłuższym przedziale czasowym - o ile bowiem samo umiejscowienie, rodzaj materiałów czy gabaryty pozostają stałe przez cały czas eksponowania obiektu, tablicy, urządzenia czy ogrodzenia, o tyle cechy stanowią kategorię, którą można utracić $\mathrm{z}$ upływem czasu. Należy dodać, że jest to jednocześnie zgodne z ratio legis art. 37a u.p.z.p., a także postanowień samej uchwały krajobrazowej. Biorąc pod uwagę możliwość długiego eksponowania reklam czy posadowienia w danym miejscu obiektów małej architektury, w przypadku braku możliwości ingerencji „na przyszłość" możliwe byłoby osiągnięcie jedynie doraźnych, a nie długofalowych skutków.

Wątpliwości pozostają natomiast, jeśli wziąć pod uwagę argument a coherentia i treść art. 37d ust. 1 u.p.z.p., zawierającego normę sankcjonującą względem przepisów uchwały krajobrazowej - według tej regulacji karę pieniężną wymierza się za umieszczenie tablicy reklamowej lub urządzenia reklamowego niezgodnego z przepisami uchwały. Brak byłoby zatem podstaw do sankcjonowania zachowania polegającego na braku właściwego utrzymywania wspomnianych obiektów, tablic, urządzeń lub ogrodzeń, które ma miejsce już po umieszczeniu. Choć nie wydaje się, by był to wystarczający argument do kwestionowania postanowień uchwały krajobrazowej, dowodzi on istnienia pewnej luki w prawie, przez którą wprowadzone regulacje co do utrzymania infrastruktury stanowią przepisy martwe.

W pełni zaś należy podzielić stanowisko Sądu, że do niemożności uregulowania w uchwale krajobrazowej kwestii utrzymania obiektów małej architektury, tablic reklamowych, urządzeń reklamowych czy ogrodzeń nie prowadzą postanowienia art. 66 ust. 1 pkt 4 p.b., według którego w przypadku stwierdzenia, iż obiekt budowlany powoduje swoim wyglądem oszpecenie otoczenia, właściwy organ (którym zgodnie z art. 83 ust. 1 p.b. jest powiatowy inspektor nadzoru budowlanego) nakazuje, w drodze decyzji, usunięcie stwierdzonych nieprawidłowości, określając

${ }^{27}$ A. Fogel, op. cit. 
termin wykonania takiego obowiązku. Argumentacja WSA w Gdańsku wydaje się jednak w tym zakresie nieco lakoniczna. Co więcej, nie do końca trafnie Sąd powołał się na fragmenty uzasadnienia projektu ustawy wprowadzającej przepisy o uchwale krajobrazowej ${ }^{28}$, dotyczące nikłej skuteczności art. 66 ust. 1 pkt 4 p.b. Należy bowiem wskazać, że za pomoca przepisów u.k. znowelizowano także przepisy innych aniżeli ustawy o planowaniu i zagospodarowaniu przestrzennym aktów prawnych, a przytoczony przez WSA fragment nie został w uzasadnieniu umieszczony w kontekście wdrożenia przepisów o uchwale krajobrazowej, ale w kontekście zmian przepisów dotyczących wprost oszpecania, o którym mowa w art. 66 ust. 1 pkt 4 p.b. (m.in. w zakresie ustanowienia możliwości nakładania wielokrotnej grzywny $)^{29}$.

Uzasadnienie wyroku w tym zakresie można by natomiast rozwinąć poprzez podkreślenie, że - na co słusznie zwracała uwagę strona w skardze - tablica reklamowa czy urządzenie reklamowe, aby mogły być uznane za obiekt budowlany, muszą być trwale związane z gruntem. Tym samym zakres przepisów prawa budowlanego oraz uchwały krajobrazowej może być zupełnie rozłączny, co już samo w sobie dowodzi, że regulacje p.b. nie są wyczerpujące. Ponadto należy zwrócić uwagę, że utrzymanie obiektów małej architektury, tablic reklamowych, urządzeń reklamowych czy ogrodzeń ma chronić nie tylko przed oszpeceniem krajobrazu, które jest uznawane za skutek zaniedbań o charakterze skrajnym ${ }^{30}$, ale też przed mniej drastycznymi, ale również negatywnymi dla krajobrazu zmianami. Co więcej, zarówno w doktrynie, jak i w orzecznictwie zauważa się, że pojęcie oszpecenia każdorazowo należy interpretować w kontekście otoczenia - innymi słowy, jeżeli dany obiekt umiejscowiony jest wśród innych zaniedbanych obiektów, uważa się, że do oszpecenia nie dochodzi ${ }^{31}$. Trudno

${ }^{28}$ Uzasadnienie do przedstawionego przez Prezydenta Rzeczypospolitej Polskiej projektu ustawy o zmianie niektórych ustaw w związku ze wzmocnieniem narzędzi ochrony krajobrazu z dnia 28 VI 2013 r., http://orka.sejm.gov.pl/Druki7ka.nsf/0/ E0EC31AF25E44523C1257BA4002A90F4/\%24File/1525.pdf (dostęp: 9 II 2020).

${ }^{29} \mathrm{~W}$ tym zakresie znowelizowano art. $121 \S 4$ Ustawy z dnia 17 VI 1966 r. o postępowaniu egzekucyjnym $\mathrm{w}$ administracji, zgodnie z którym jeżeli egzekucja dotyczy spełnienia przez zobowiązanego obowiązku wynikającego z przepisów prawa budowlanego, grzywna w celu przymuszenia jest jednorazowa, chyba że dotyczy obowiązku utrzymania obiektu budowlanego w stanie nieoszpecającym otoczenia.

${ }^{30}$ Wyrok NSA - Ośrodek Zamiejscowy w Szczecinie z 19 XI 2003 r., sygn. SA/Sz 2255/01.

${ }^{31}$ Zob. J. Murzydło, Prawo budowlane a budynki oszpecajace otoczenie, "Państwo i Prawo" 2007, z. 4, s. 95-99. W artykule tym autor powołuje następujący przykład: „Kamienica 
zaś uznać, by w zakresie ochrony krajobrazu mechanizm taki uznać za wystarczający - uniemożliwiałby on bowiem ingerencję, w sytuacji gdy naruszona jest estetyka wszystkich elementów krajobrazu.

\section{Podsumowanie}

Stanowisko WSA w Gdańsku wyrażone w wyroku z 18 września 2018 r., sygn. II SA/Gd 328/18, należy uznać za słuszne, choć nie zawsze argumentacja za danym podejściem została przez sąd przeprowadzona w sposób w pełni przekonujący i wyczerpujący.

Podsumowując najważniejsze aspekty omawianego wyroku, należy zauważyć, po pierwsze, że brak jest wystarczających podstaw, by z zakresu przedmiotowego uchwał krajobrazowych wyłączyć materiały publikowane $\mathrm{w}$ ramach kampanii wyborczych lub referendalnych. Wręcz przeciwnie - jak słusznie uznał sąd, uregulowanie kwestii ich sytuowania, gabarytów, standardów jakościowych czy też rodzaju materiałów, z jakich mają być wykonane, znajduje uzasadnienie językowe w przepisach ustawy o planowaniu i zagospodarowaniu przestrzennym, a także systemowe $\mathrm{w}$ zestawieniu z przepisami kodeksu wyborczego oraz funkcjonalne przy uwzględnieniu specyfiki tego typu reklam oraz ratio legis uchwał krajobrazowych.

Po drugie, na aprobatę zasługuje stanowisko, zgodnie z którym władztwo gmin w zakresie kształtowania postanowień uchwał krajobrazowych obejmuje kwestie ustalania minimalnej odległości tablic czy urządzeń reklamowych od elementów infrastruktury drogowej, nie powodując sprzeczności z przepisami u.d.p. Podejście Sądu w tej materii, oparte głównie na argumentacji funkcjonalnej, należy uznać za prawidłowe, a jednocześnie zgodne z ugruntowaną linią orzeczniczą w podobnych sprawach.

Wreszcie, po trzecie, zgodzić się należy z Sądem, że uchwała krajobrazowa nie musi się ograniczać do regulowania warunków, jakie mają spełniać obiekty małej architektury, tablice czy urządzenia reklamowe na moment ich sytuowania, a może dotyczyć także i stanu

z opadającym tynkiem i złuszczającą się farbą będzie spełniała powyższą przesłankę [art. 66 ust. 1 pkt 3 ustawy z 1994 r. - Prawo budowlane], o ile pozostałe kamienice, sąsiadujące z nia, będą zadbane, estetyczne. Odmienna sytuacja zaistnieje, jeśli znajdować się ona będzie w sąsiedztwie innych, zniszczonych kamienic. Ocena konkretnego budynku uzależniona byłaby więc od stanu innych budynków znajdujących się w jego otoczeniu". 
w późniejszym czasie. Choć argumentacja Sądu w tym zakresie nie zawsze jest wystarczająca i trafna, sama istota problemu wydaje się prawidłowo rozstrzygnięta. Choć znów przesądzające w tym zakresie sa, jak się zdaje, argumenty natury funkcjonalnej, nie jest niemożliwe znalezienie oparcia dla nich również w wykładni językowej czy systemowej.

Na koniec warto podkreślić, że choć omawiane orzeczenie zapadło w konkretnej sprawie i dotyczyło postanowień konkretnej uchwały, przedstawione $\mathrm{w}$ nim tezy mogą mieć znaczenie dla szerszego grona podmiotów. Problemy, do jakich odniesiono się w wyroku, nie są bowiem niszowe i z dużą dozą prawdopodobieństwa można stwierdzić, że dotyczą krajobrazu w każdej z gmin, która zdecydowała się bądź zamierza w przyszłości zdecydować się na przyjęcie uchwały, o której mowa w art. 37a u.p.z.p. Pozytywne rozstrzygnięcie (zgodne z intencją gminy, a także ratio legis u.p.z.p. oraz samej uchwały) rodzi zatem nadzieję na efektywniejszą ochronę krajobrazu.

\section{THE MATERIAL SCOPE OF THE "LANDSCAPE RESOLUTION". COMMENTS ON THE JUDGMENT OF THE PROVINCIAL ADMINISTRATIVE COURT IN GDAŃSK OF 18 SEPTEMBER 2018, REF. II SA/GD 328/18}

\section{S u m mary}

The text concerns an analysis of theses and justification for the judgment of Province Administrative Court in Gdańsk dated 18 September 2018 (case no. II SA/Gd $328 / 18)$. Although the judgment is based on particular factual state of affairs, its conclusions seem to be connected with common problems in the area of so-called 'landscape acts' adopted at the municipal level.

Firstly, the judgment states that landscape acts may refer to campaign materials presented in connection with elections or referendum. In the commentary, this approach is approved, although the reasoning is developed via a detailed interpretation of the spatial management and planning act and electoral code. Later in the judgment it is claimed that landscape acts may cover rules of locating advertisements nearby elements of the road infrastructure. Moreover, this standpoint is shared in the gloss, detailed relations between landscape act and act on public roads as well as judgments in similar cases have been additionally presented.

The last issue raised in the judgment was the problem of the legal grounds of imposing an obligation to maintain small architecture objects, advertisement boards / units and fences in the proper condition. As the court claimed, this is possible, because maintenance of the object is the element of its location, and this is also connected with the obligation to use high-quality materials. Moreover, it is stated 
that the problem of maintaining these objects has not been fully regulated in building law. This approach is accepted in the gloss, although attention is drawn to some inconsistencies in the justification, as well as to the possibility of raising other, more accurate arguments by the court.

Keywords: landscape act - protection of landscape - advertisement - advertisement board - advertisement unit

\section{LITERATURA}

Banaszak B., Kodeks wyborczy. Komentarz, Warszawa 2020.

Bąkowski T., Zakres swobody $i$ władztwa planistycznego gminy w kształtowaniu treści uchwały krajobrazowej, "Gdańskie Studia Prawnicze” 2017, nr 2.

Fogel A., Goleń G., Staniewska A., Komentarz do art. 7 ustawy krajobrazowej, w: Ustawa krajobrazowa. Komentarz do przepisów wprowadzonych w związu ze wzmocnieniem narzedzi ochrony krajobrazu, pod red. A. Fogel, Warszawa 2016.

Murzydło J., Prawo budowlane a budynki oszpecajace otoczenie, "Państwo i Prawo" 2007, z. 4.

Plucińska-Filipowicz B., Kosicki A., Komentarz do art. 37c ustawy o planowaniu i zagospodarowaniu przestrzennym, w: Ustawa o planowaniu i zagospodarowaniu przestrzennym. Komentarz aktualizowany, pod red. A. Plucińskiej-Filipowicz, M. Wierzbowskiego, Warszawa 2019.

Słownik współczesnego języka polskiego, t. 2, pod red. B. Dunaja, Warszawa 1998. 